\title{
Feminist collaborations in higher education: Stretched across career stages
}

\author{
Maddie Breeze, Yvette Taylor \\ School of Education, University of Strathclyde, Glasgow, United Kingdom \\ maddie.breeze@strath.ac.uk, LH206, Lord Hope Building, 141 St James Rd, Glasgow \\ G4 0LT, 01414448072 \\ yvette.taylor@strath.ac.uk, LH209 Lord Hope Building, 141 St James Rd, Glasgow G4 \\ OLT, 01414448048 \\ Dr Maddie Breeze is Chancellor's Fellow in the School of Education, University of Strathclyde. Previously she \\ worked as a Lecturer in Public Sociology at Queen Margaret University, Edinburgh and as a Research Associate in \\ Sociology at the University of Edinburgh. \\ Prof Yvette Taylor is Professor of Education, and Research Director in the School of Education, University of \\ Strathclyde. Yvette was previously (2011-2015) Head of the Weeks Centre for Social and Policy Research, London \\ South Bank University.
}

\begin{abstract}
Categorical career stages offer an institutional framework through which mobilities can be claimed and contested by feminists in academia. Inhabiting career stages uncritically can serve to reproduce neoliberal academic structures that feminists may seek to resist. Collaboration across career stages is a significant empirical case for understanding how feminists occupy academic space. We use auto-ethnographic methods to read career stages and feminist collaboration through each other, analysing the authors' cross-career collaborations and mentoring relationship in a Scottish University. We ask how feminist collaboration can claim and disrupt the neoliberal temporal logics of competitively achieving individuals on upward career trajectories, where academic arrival can feel permanently deferred. As such we argue for more pluralised and fragmented understandings of 'career stages', which as fixed categories work to position academics as either precarious or privileged, and for a messier imaginary of academic work and careers.
\end{abstract}




\section{Introduction}

The university is a workplace where being and 'becoming', or 'arriving' as an academic can feel stretched, and even permanently deferred (Taylor 2014), as everyday work goals become an 'ever-receding horizon that cannot be reached' (Pereira 2016: 106). It is well established that becoming-academic is shaped by intersecting regimes of inequality. In this context, 'early' 'mid' and 'established' career categories offer an institutional framework through which feminists can claim and contest academic mobilities. This framework interacts with the performative demands of the university, and implies competitive individual labouring subjects, upwardly mobile on smooth, linear career trajectories, always stretching for the next stage, never quite getting there. These stretches are visible in academic 'corridor talk' (Pereira 2017) and online spaces (Costa 2018) as academics reflect upon the conditions of their work. As de Cruz (2016 np) has pointed out, the assumed 'happily ever after' of an academic career 'on track' disguises how 'obtaining a permanent position is only the beginning'.

Inhabiting career stage categories uncritically can serve to reproduce neoliberal academic structures that feminists may seek to resist and rework, labouring 'to question and transform... institutions of knowledge production' (Pereira 2012: 283). Feminist academics have long attended to the politics of work, and as universities 'push us to work harder, sell ourselves better and engage in competition rather than collaboration' (Gill and Donaghue 2016: 93) collaboration across career stages becomes an important empirical case for understanding how feminist academics work to take up space higher education.

Across national contexts, making and maintaining space for feminists and feminisms in higher education takes a great deal of work (Acker and Armenti 2004, Acker and Wagner 2017). This includes the - often institutionally unrecognised and 
unrewarded - work of collaboration. Collaboration encompasses both how 'early career' academics are mentored and supported by 'senior' colleagues, and how large research grants and teaching teams can rely on the casualised labour of $\mathrm{PhD}$ students and post-docs.

'Early career' status is increasingly subject to critical attention, and is a category around which action against exploitative employment practices coalesce. It is also an expanding category, stretching to include longer periods from $\mathrm{PhD}$ completion, just as short-term research and teaching contracts proliferate beyond the 'early' career. Gill and Donaghue (2016:93) remind us that an exclusive focus on the problems faced by early career academics risks ignoring how these are embedded in broader 'toxic and increasingly unstable work relations'- manifest across the academic life course. We add the suggestion that if the insecurity of early career status is understood in a relationship of antagonism and/or of smooth, linear progression to 'later' career stages then we reproduce the individualizing and competitive meritocratic logics of 'career stage' themselves.

Likewise 'established' career categories and academic leadership are subject to critical feminist attention, and achieving positions of power in universities can be understood as a strategy for feminist institutional change (Morley 2013; Redmond et al 2017; Spanò 2017). Morley (2013: 116) is cautious about seeing seniority as the measure of feminist academic success, since leadership can 'mean incorporation into masculinist managerial practices'. There is an emergent orientation in book-length publications towards career stages; Generation and gender in academia (Bagilhole and White 2013), Being an early career feminist in a changing academy (Thwaites and Pressland 2016), Inside the ivory tower (Gabriel and Tate 2017) and (Taylor and Lahad 
2018). This article furthers these contemporary debates using auto-ethnographic methods to read categorical career stages and feminist collaboration through each other.

Understandings of the relationship between early career and established academics are vulnerable to over-simplification, either as a relation exclusively of exploitation (early career research and teaching assistants are not recognised or rewarded for their work, from which more established colleagues benefit) or of entitlement (established academics are obligated and expected to do the unrecognised and unrewarded work of mentoring and supporting early career colleagues). Here we explore the messier space in-between such categorical understandings of collaboration across the career stage.

In this article we 1) discuss definitions of academic career stages and their production 2) review literature on feminist academic work in the context of 'neoliberal' 'entrepreneurial' universities (Gill and Donaghue 2016; Taylor 2014), and raise questions about career categories and feminist collaboration 3) situate our autoethnographic methods and feminist methodology 4) present a conversation between the authors, exploring our cross-career collaboration and mentoring relationship in order to analyse how feminist cross-career collaboration can both claim and disrupt normative conceptions of the competitively achieving individual progressing through categorical

career stages. Cross-career feminist collaborations both occupy and stretch the temporal logics of career stages. We conclude with an argument for more pluralised and fragmented understandings of 'career stages', beyond either precarity or privilege, and make the case for a messier imaginary of feminist academic work and careers.

\section{Defining Career Stages}

In UK Social Sciences and Humanities, the post-PhD academic career trajectory is commonly understood to involve progression through: Post-doctoral Researcher and/or 
Teaching Fellow, Lecturer, Senior Lecturer, Reader, Professor (Wakeling, 2010).

Feminist critiques of this trajectory include how: 'interruptions' to smooth progression (parental leave, caring responsibilities, ill health), the work and networks that enable such a progression (mentorship from senior colleagues, research and teaching assistants, domestic and emotional labour), and other forms of knowledge and expertize (community projects, activism, and everyday life) are all written out of diagrams of the career trajectory. The hidden curriculum and 'rules of the game' (Morley 2013, Addison, 2012), including how intersections of class, race, gender structure academic careers and promotions, are rarely acknowledged. Likewise, the exponential growth in the number of women attending HE as undergraduate students (Leathwood and Read 2009) is not matched at post-graduate level (UNESCO, 2014).

\section{'Early Career'}

'Early career researcher' (ECR) is defined differently by RCUK funders, with eligibility criteria for 'early career' funding schemes varying from a maximum of four (ESRC) to eight (AHRC) years since PhD completion. The European Research Council's (ERC) 'Starting Grants' ask for two to seven years of post-doctoral experience (ERC 2017a). Eligibility criteria specify how career breaks and part-time employment interact with 'early career' status, as well as further defining both 'first academic appointment' $\left(\right.$ AHRC 2017) ${ }^{1}$ and sub-categories of 'early career' (ESRC 2017)².

${ }^{1}$ The AHRC's (2017: 53) definition of ECR is within eight years of $\mathrm{PhD}$ award, or within six years of first academic appointment and these durations exclude career breaks. 'First academic appointment' is defined as the first paid full or part time employment contract, which lists research and/or teaching as primary functions.

${ }^{2}$ The ESRC sub-divides 'early career' into three further 'distinct stages': 'doctoral, immediately post-doctorate, [and] transition to independent researcher' (ESRC 2017). 
Variation in definitions of 'early career' shows us that this is a contested category, with eligibility for (fiercely competitive) funding schemes at stake ${ }^{3}$. Early career status becomes a location from which claims are made, for access to resources and recognitions, such as reduced outputs for REF submissions. As we write, the parameters of the Research Excellence Framework (REF) 2021 are being negotiated, and questions on output 'portability' articulate contested norms around career mobility with implications for both 'early career' academics and institutions seeking to 'game' the system. Early career as a category does not account for those scholars who having been awarded a $\mathrm{PhD}$ then leave academia, although this is implicitly acknowledged in the allowance for institutions to submit outputs of academics who no longer work in the sector for REF 2021.

As casualization is normalised in higher education (Gill and Donaghue 2016) alongside expectations of inter/national mobility, it can be extremely difficult for 'early career' academics to plan their lives more than a few months ahead, let alone strategise a career. It is important to locate academic work in a broader employment landscape increasingly characterised by long-term precarity. In this context, while early career academics face an inhospitable climate, early career as a career stage category articulates the achievement and award of a $\mathrm{PhD}$, academic 'success', a form of 'arrival' in a sector that holds out the promise of fulfilling, secure, long-term employment for some. Being 'early career' is a category around which claims and mobilities cohere.

\footnotetext{
${ }^{3}$ Such eligibility is often complicated by funders' requirements that a candidate move institutions (e.g. Leverhulme Early Career Fellowships), countries (Marie Curie), or already be employed on an academic contract that will last the duration of the proposed project (e.g. Carnegie Trust Research Incentive Grants) and the requirement that candidates identify a mentor at the host institution.
} 
Early career academics occupy an ambivalent space of (relative) privilege and (relative) precarity, depending on other forms of e.g. gender, race, and class (dis)advantage. Early career status is contested, early career work is casualized, and for some, strategic claims to resources and mobilities (including support from more 'senior' academics) are made from this location.

\section{Mid Career}

'Mid career' is another potentially plastic category, the boundaries of which can be unclear. The ERC (2017b) Consolidator Grant invites submissions from researchers with seven to twelve years experience since completion of a $\mathrm{PhD}$, yet incongruously addresses applicants as 'young scientists'. It is tempting to define 'mid' career by the achievement of a permanent position, the pursuit of which so characterizes 'early career' status. However, according to Carey's advice (2014 np) promotion to Senior Lecturer 'marks entry into the mid-point range of a full academic career', underscoring the striving mobile subject 'laying the ground work in the early years' and 'looking ahead' to future promotions (ibid). Once mid-career status is achieved, the question 'now what?' is immediately raised (ibid). Such instruction demonstrates the half-way status of this 'middle' stage, and re-inscribes the never-quite-getting-there temporality of space-time in neoliberal academia (Henderson 2018). Yet for many academics, Lecturer or Senior Lecturer posts can represent the 'end point' of an academic career.

While the amount of teaching, research, and administration experience necessary for Lecturer and Senior Lecturer posts is documented and produced in job role descriptions, workload allocations, and annual development review processes, this varies across and within institutions and departments, as does the kind of work that is rewarded by promotion. Advice on transitioning into, and progressing beyond, 'mid career' does not often attend to the hidden curriculum and barriers to promotion 
(Morley 2013). It does however reflect the importance of 'being on time', as categorical career stages position some academics as 'too early' or 'too late' for the most established career categories, and lecturers can get stuck, 'trapped', or 'caught' in their careers (Angervall 2016:1)

\section{'Established' Career}

'Established' career does not present a homogeneous category either, and the voices of senior scholars draw attention to non-standardised career pathways (Acker and Wagner 2017; Bagilhole and White 2013), such as coming to academia 'late', or writing PhDs after working in universities for many years. Defining an 'established' career stage is complicated by how not all academics become Professors, and few will take up a place on senior management teams.

In the UK women currently account for $45 \%$ of academics at universities, however they occupy only around $24 \%$ of professorships (Equality Challenge Unit 2017). Black and Minority Ethnic (BME) women are starkly underrepresented (Mirza 2017: 39 ): $69.4 \%$ of professors are white men; $22.6 \%$ are white women; but only $6.2 \%$ are BME men and 1.7\% are BME women (Equality Challenge Unit 2017; and see Alexander and Arday 2015). This translates to around 30 Black women professors in the UK (Mirza 2017: 39). Not only are women and especially BME women underrepresented in senior positions, they are also paid less, and are more likely to be found on casual contracts (Equality Challenge Unit 2017).

Morley (2013:116) argues that women's leadership capacities in HE are 'relentless[ly] misregoni[sed]', and women are over-burdened with low-level, highvolume administrative academic 'housework' (Heijstraa et al 2017). Women's presence is both reduced and inflated when rendered in brightly coloured exaggerations for example in photographs of always-smiling 'women leading the UK's top universities' 
(The Guardian 2015). Here 'overcoming gender equalities' can be presented as an individual achievement, of remarkably successful middle class white women, demonstrating 'resilience' in the face of 'adversity' (Redmond et al 2017), which echoes McRobbie's (2009) analysis of 'post-feminism' and 'reconstructs the serious intellectual subject as a masculine one' (Leathwood: 2013: 133). Of course, such success is only remarkable because so few women occupy positions of power within universities; as Ahmed (2017) shows, feminist work is necessary because the university is not feminist.

An exclusive focus on women in positions of (corporate) leadership can depoliticize feminism, acting as a window dressing public relations strategy (Foster 2016). For Morley (2013: 117) 'mere representation, or counting more women in, is [not] the main goal for gender equality and redistributive justice'. In this context an awkward question concerns the expectations placed upon feminist professors, once they have 'arrived' in established career positions, who are they expected to care for, and collaborative with? As we read announcements on REF 2021, and learn that universities may submit the publications of academics who have retired (or died), it is clear that this 'late' career stage is just as malleable and stretched as those that precede it.

Clearly, there are aggregate material differences between academics at the beginnings, middles or ends of their careers, and future-orientations can seduce us, in narratives that promise if... when... then... if we just strive harder then we will 'get there' (Hey 2001: 80). However, categorical distinctions of career stages, within which the striving individual competes with others for promotion, efface not only the well-documented structural barriers to career 'progression', but differences between academics within each category and the potential connections and complexities between 'career stages'. With this in mind we turn to how feminist academic work and collaboration are 
currently understood, particularly in relation to career-stage temporality as it inflects how we make space for feminism in neoliberal universities.

\section{Feminist Academic Stretches}

One consequence of the intensification and acceleration of work in the 'greedy institution' (Hey 2004: 33) is that academic workers are 'time squeezed' in managerial attempts to fit as much work as possible into as little time as possible (Southerton, 2003); 'stretch[ing] the week and themselves' (Taylor 2012: 264), 'working harder and sleeping less' (Acker and Armenti 2004: 3). With the proliferation of audit cultures and their internalisation, feminist academics are pressured to work instrumentally within the terms of performance metrics. However, feminist academics are not passive participants within these parameters, and the agency feminist scholars exercise is visible in how they take up space within neoliberal universities (Breeze 2018).

The uneasy congruence between feminist cross-career collaboration and the performative demands of the neoliberal university is contextualised by how the commercialization of UK HE and the re-positioning of students as consumers allowed a 'paradoxical' expansion of Women's Studies through the rapid growth in student numbers (Skeggs 1995). The recognition of feminist scholarship's financial value can be essential to its institutionalisation (Pereira 2015: 287), which is often contingent on the performance of individual feminists (Pereira 2017). When competitive individualism is ‘built-into' academic performance management (Acker and Wagner 2017: 8), and feminist academic-activism includes resisting 'individual solutions' to structural problems (Pereira 2016: 105), collaboration is often positioned as feminist praxis. For example, The Res-sisters (2016: 267) argue that collectivity disrupts neoliberal individualism, and that 'we must remind ourselves that we are working in 
academia for the pursuit of knowledge and the pursuit of equality for all, not for our own career advancement'.

Within the frame of collaboration-as-resistance, existing literature approaches feminist collaboration in three related ways. Firstly, horizontal ways of working are understood as 'essential for well-being at work' in the face of competitive individualism (Gannon et al 2015: 189-191). Secondly, support networks are seen as necessary to buffer entrenched 'old boys networks' (Bagilhole and White 2013). Collaboration can support 'alternative career strategies' (Angervall 2016), which informs how thirdly, mentoring relationships with more experienced feminist academics are positioned as vital to career progression (Redmond et al 2017: 335-336; Bagilhole and White 2013, Equality Challenge Unit 2017). However, feminists have attended to complications in collaboration-as-resistance, 'there is this fantasy around feminist research that we can all work collaboratively, but people still have careers' (Acker and Wagner 2017: 11). Collaboration-as-resistance can reinscribe normative assumptions about women as innately nurturing, feeding into disproportionate responsibility for doing gender diversity work, with women 'sacrificing [their own] career gains' to support others (Pearce 2017: 15).

Mentorship, a specific form of cross-career collaboration, is also understood as feminist praxis (Handforth and Taylor 2016). Acker and Wagner (2017: 11) found that feminist research leaders were 'determin[ed] to support and mentor junior colleagues', and saw mentorship as an 'integral' feminist commitment. Concurrently, mentoring can go unrecognised and unrewarded by universities, just as the work of forming teams and securing positions for junior colleges is 'barely credited' (Acker and Wagner 2017). The work of supporting early career colleagues can also be structurally limited, as when established feminist academics' efforts to secure funding often result in casualised 
contracts for early career colleagues (Acker and Wagner 2017). Here we begin to see how cross-career collaboration, and specifically mentorship, can be experienced as an obligation (by 'established' mentors) and as an entitlement (by 'early career' mentees). Not only is the work of feminist mentorship devalued, it is co-opted in institutional mentoring schemes, as in Athena SWAN's focus on supporting early- and mid-career women (Pearce 2017); 'universities simultaneously repudiate and depend on feminized forms of labour' (Gannon et al 2015 195). This seeming paradox, in which feminist work is vulnerable to incorporation into - and implicated in - the neoliberal academic structures and subjectivities which it also seeks to transform, informs our autoethnographic investigation of cross-career collaborations, asking how such collaborations both claim and disrupt the neoliberal temporal logics of competitively achieving, upwardly mobile individual feminist academic subjects.

\section{Methods}

This research paper grew from our experiences working together from different academic career locations; an established feminist professor (a white woman from a working-class background) and an early career academic (a white woman from a middle-class background). We situate ourselves in these class-race-gender locations as part of the broader project of fracturing the sometimes-assumed homogeneity of career categories, and we hope that by using 'The' early career academic and 'The' feminist professor below we draw attention to the totalising effects of such career designations. However, we also hesitate around the politics and epistemologies of such (dis)identifications, and are wary of uncritically claiming to speak from avowedly authentic subject positions. Some of our previous work (Taylor 2013) can pre-emptively and endlessly 'out' us, as queer, for instance (Ahmed 2012; Tauquir et al. 2011). There is a repetitive labour in claiming and naming e.g. a working-class background in which 
we struggle to stretch beyond 'the individual uptake of space' (Taylor 2012: 52).

Our collaboration began in October 2015 as The Feminist Professor took up a post at a Scottish University and The Early Career Academic applied to a Chancellor's Fellow ${ }^{4}$ post at the same institution. We worked together on funding bids, seminar series, journal special issues, and edited collections, and the Feminist Professor mentored the (potential) Chancellor's Fellow's job applications. As these projects progressed we articulated a sense of our collaboration as stretching the understandings of career categories. This inspired us to turn to our experiences as a source of data for theorising feminist collaboration across career stages.

Since Gill observed that 'the experiences of academics have somehow largely escaped critical attention' (2010: 229) an emergent body of work has developed autobiographical and auto-ethnographic methods for studying academics and academic work (Breeze 2018; Quinn et al 2014; Spirit et al 2017; Taylor 2012, 2013). However, these methods for exploring the 'new laboring [academic] subjectivities' (Gill, 2014: 12) take place in the context of much longer histories of feminist methodology and epistemology that prioritize experiential ways of knowing (Stanley 1993). This includes the methodological and epistemological debates around feminist standpoint theory (Harding, 1997; Hartstock, 1997; Smith, 1997), and Black feminist thought (Bhambra 2015; Hill Collins 1990; Mirza 1997), as well as long-standing use of personal narrative by working-class feminist academics to explore classed and gendered experiences of the academy (Holloway 1997; Morley 1997; Reay 1997).

\footnotetext{
${ }^{4}$ The 'Chancellor's Fellowship' is a lecturer role which includes a contractual arrangement to achieve 'fast track' promotion to Senior Lecturer within five years of appointment.
} 
Through these debates, the epistemological status of experience has been problematized, showing how 'feminist knowledge' and 'women's experience' have never been homogenous and are marked by unjust (raced, classed) power relations. Experience cannot be taken to speak for itself (Walker 1997). There is a risk of uncritically drawing on our collaboration as authentic experience, 'transparent empirical data' or 'pure truth' (Gannon et al 2015). We follow precedents then, for auto/biography as 'signalling the active inquiring presence of sociologists in constructing, rather than discovering, knowledge' (Stanley 1993: 41). Collective biographical methods are particularly appropriate to our aims, allowing as they do for the recognition of discursive effects, of ‘subjects-in-relation' and 'subjects-in-process' (Davies and Gannon 2012: 79; Gannon et al 2018), and the 'collaging individual stories to undermine the notion of narratives as individual' (Spirit et al 2017: 2).

Indeed, feminist collaborations, especially collaborative writing, can be methods of inquiry in their own right (Handforth and Taylor 2016; Spirit et al 2017). Personal narratives are often used to understand feminists' career trajectories and are ideal for exploring 'the relational complexities of academic work' (Gannon et al 2015: 190). We are inspired by Quinn et al. (2014: 208) who developed their theorising in on-going group discussion between the six authors 'rather than [...] in isolation by the lone intellectual'.

Putting these collaborative auto-ethnographic methods to work, we analyse our collaborations and mentoring relationship, as authors differently located in career stage categories; The Feminist Professor and The Early Career Feminist. We present a conversation between ourselves, crafted using our (long, multiple) email exchanges from 2015 onwards, our diaries, calendars and notes, our job descriptions, and online academic 'corridor talk' as fragments and prompts. In writing this conversation we met 
face-to-face to discuss the everyday details and discursive construction of our collaborations. Through these discussions our focus narrowed to a single meeting, in a café one evening in December 2016.

We met to discuss The Early Career Feminist's second application to the Chancellor's Fellowship Scheme, in The Feminist Professor's department. Selecting this one encounter allows us to situate our collaboration in relation to our institutionally structured career stage locations. We first wrote our own accounts of the meeting, and then began to weave them together, sending iterative drafts via email, often in the stretched academic time between teaching, administration and other research activities. These methods allowed us to use 'each other's stories to complicate our own experiences' (Spirit et al 2017: 3). Writing this paper collaboratively then articulates more than a simple 'writing up' of our analysis and interpretation of 'the data'. We are analysing cross-career feminist collaborations in and through our continuing crosscareer feminist collaboration.

\section{Stretched Across Career Stages}

\section{Doing Feminist Work}

It's the limbo time between Christmas and New Year, the evenings are dark, cold and damp, it takes about twenty minutes to walk from my flat to the cafe. I'm excited and nervous to talk about the upcoming job interview. I'm pretty delighted just to have made the shortlist, and I'm not really letting myself imagine how good it would be to get the job, or that I might actually be in with a chance this time.

5 The Early Career Feminist speaks in non-italic text, The Feminist Professor speaks in italic text. 
It would be great to have more feminist scholarship represented in the School; it would be great to have more feminists... I've read the forms, the emails, the criteria, the sense of competition and the claims for candidacy. I've ranked and rated, and I am invested. I have a sense of the likely panel and the talk-to-School presentation: I'll be there, encouraging more feminist scholarship. But how to 'be there'? Am I an insider or on the outside, rendering myself invisible in the effort to make feminist scholarship visible? Doing more than simply viewing and scoring applications 'objectively'.

I'm walking through the cold dark now because I emailed her - The Feminist Professor - about a year ago, in the Autumn of 2015. I was working as a tutor, less than two days a week, on temporary contracts. I didn't think that an academic career was necessarily going to work out. I had been staying at a friend's house since the beginning of the year, sleeping on a mattress in her box room. The convener of one of the courses I tutored on suggested I apply for the Chancellor's Fellow post, told me The Feminist Professor was moving there soon, and said I should email her, expressing an interest in the post.

We arrange to meet, during the Christmas holidays, and after I've read the application many times, re-phrasing and re-presenting ('you have to fit into the School'). My inbox has held many queries, expectations and aspirations since the call for candidacy circulated - an 'early career opportunity', not to be overlooked, promising supported scholarship, expecting cutting edge contributions. Everyone has ideas of what constitutes a contribution, though... How often has feminism (and 'the feminist') heldand failed - in 'contributing'. She contributes in holding and guiding others through institutional expectations and legitimations, but she risks failing in those expectations and legitimations too, placed potentially as too niche as sub-disciplinary, rather than inter-disciplinary, and as excessive rather than depleted ('we have feminists already', 'you do that work'). 


\section{Career Categories: A Chance, A Claim}

This was a new thing for me, I wouldn't have thought to email The Feminist Professor if my colleague hadn't suggested it. I knew her work, and had seen her talk, but we didn't know each other, why would she be interested in working with me, helping me?! I emailed - seeking her opinion on whether I should apply, was it worth the application? She replies that I should, and more than this starts to give me advice. We plan to talk on Skype the following week. Between teaching classes I sneak into a university room to use a computer, I had the access code to one tiny cupboard 'editing suit' room, from being previously employed to make 'blended learning' videos. I hoped that no one would knock on the door with more legitimate purposes, catch me and kick me out. Feminist scholarship has, I know, long problematized invisible labour, and maybe I am setting myself up for another fall, reaching-out to early career applicants, offering support, and aware that I've also felt that 'support' to be demanded, expected and entitled (and to feel myself as failing that claim). To claim in the name of feminism as 'that's what's senior women should do', has rendered me exhausted. Is feminism exhausting? It's her second try at this annual round, she's in a better place, she's more competitive and impactful, she has a chance....

My 2015 application didn't get shortlisted, but we kept in touch. I don't know whether it is more appropriate to say that the Feminist Professor began mentoring me, or to say that we began working together. I think both are correct, but it is interesting to put them side-by-side and see where the emphasis falls. In 2016 she agreed to mentor my bid to the Leverhulme Early Career Fellowship scheme (also unsuccessful). In the language of early career funding guidelines I had identified a mentor at the host institution. She patiently read and re-read messy and incomplete drafts of my bid, and consistently 
offered invaluable advice and insights. Apart from $\mathrm{PhD}$ supervisors, I hadn't ever really worked with a Professor in this way, I felt embarrassed sharing my half-finished ideas, like a clumsy - needy - child.

This sense of going forward (and returning 'back'), caused recent pause when a colleague asked me if I thought I had 'peaked too soon'? Feminist research in particular has been critical of the travelling subject (or 'mobile self'), who ascends, and tells only their own story.... But is her potential already being recast as a failure? The sense of being in the wrong time (too young to be a successful academic) is transmitted in these exchanges... Even (feminist) successes may be recast as failures in normative measures of fitting-in, moving, achieving and (not) caring and the question of what it means to live out, activate and be present in and through academia become pressing issues...'

I was going to write that I hadn't worked with a 'senior' academic in this way before, and hesitated over this terminology. She has much more experience, knowledge, and expertize than I do, and many more achievements - but she's not elderly! When we are placed within and place ourselves within the categorical framework of career stages she is senior, I am junior. Perhaps I was toddling around smearing food all over my face and she was gently but firmly suggesting that I use a knife and fork, showing me how. In 2016 the Chancellors' Fellowships were announced again, and again I applied. This time round I had demonstrable connections with the department, a collaborative large grant almost ready for submission, and co-authored publications underway. I'd won a book award and written a five-year research plan. I was becoming a credible candidate.

She'd just won a prestigious prize (at a prestigious conference): praise was rightfully delivered and she basked in the glory, in the surprise that seemed to say she'd arrived 
in academia (early career no more). But she was worried. Did this really signal a safety in arriving, a recognition of value, labour, contributions? Or did it signal more labour, maybe this time without recognition or value? When the stakes are set so high do we have no choice but to keep apace, to endlessly indicate, effect and fear our own (in) capacities? When we compete with colleagues in a competitive universitymarketplace - and when competition is so close it is generated by-ourselves-forourselves (as 'keeping up', 'what next?') - what cares, connections, capacities are rendered near and far? I tell her to add her award to her email signature, a neat summary quickly conveying who she is as a hyperlinked bio. But I pause. There's a borderline between the achieving academic, the celebrity star and the pretentious, (self)promotional subject. I pause over these laboured cares.

I am ambivalent about The Prize. I didn't often do this, but when colleagues congratulate I itched to unsettle the narrative of success that such a prize announces itself as evidence of. I want to talk about how I wrote the book 'between jobs', on a 10 hour per week six month contract. I wrote the book while I couldn't afford rent. I don't know how to tell this story without positioning myself as heroically bootstrapping... I hesitate over my self-promotional email signature. Perhaps my reluctance is because I want to hang on to 'early career' status, I only finished my $\mathrm{PhD}$ two, three, four years ago... eligibility for 'early career' funding recedes in the rear view mirror. I want to hold on to this 'early' status, with its inferences of eligibility and connotations of having only just arrived, without getting stuck. I am warned, repeatedly, not to 'get stuck' on a teaching-only contract, at a non-elite university. My $\mathrm{PhD}$ supervisor tells me, 'you wont have any problems now, the prize lets everyone know that you are real star quality'. I wrote the book before I got a 'proper' academic job, and after the prize it took another year to achieve a longer term, full time contract. In these moments I want to show that 
this is what 'success' sometimes looks like, clapping and congratulations and celebration without secure employment. I won a prize but I only have a job for the next two months is not an appropriate email signature! During the Chancellor's Fellowship interview, a panel member asks me, 'is it usual for this prize to be given to someone as young as you?' I don't know what he is asking me... he prompts 'are other winners usually more established in their careers?'

\section{Getting There}

I hurry to the café, I don't want to be late! I feel gratitude - and indebtedness. I still don't really understand why The Feminist Professor is helping me, why she would want to work with me - and I don't want to let her down. If I don't get this job, or get some funding soon, surely all her efforts will have gone to waste! She's meeting me now, when universities are closed, in the evening, on her own time. We're both meeting on our own time. I don't want to be a waste of her time.

How long to keep trying, to just stay in the same place - to move around geographically, while staying on the same bottom rung? She'd put in the long-hours but was still stuck in the expanded category of 'early career'. She feared that she would be letting the feminist side down. The sides in academia are often sharp and painful and despite our tries, these persist. 'Sides' stick out as barriers to entrance, as promotional hurdles, in recognized 'achievers' - or 'drop outs'. My colleague, contributor and competent academic feared she was on the wrong side: non-academic. Friends console, offer support, sympathise with the tough soul-searching and decision making when academia is something more than just a job. We write our sympathies and supports in between emails as other urgencies come through our inbox (from students, colleagues, funders, unions). How much to keep trying and caring, with the inbox, the entrance and 
endurance in higher education as painful sides pressing against us.

At the cafe I scribble furiously, pages and pages, trying to write down everything she says. The brief for the interview presentation instructs that I should present on my research achievements, plans, and vision. I tell The Feminist Professor this, and she replies straight away that achievements means publications, plans means funding, and vision means how my research aligned with the university's - and department's strategy and themes. I scrawled this out in my notebook, in capital letters, taking up a whole page.

All the information is held in my head, what to say, how to present, how to nuance and adapt, to fit the collective, while also being independent, unique - do bring something new! I speak fast and pages of notes are written as we sit during our holidays, revisiting the application and rehearsing issues and likely interview questions. I wonder if I am frightening the applicant, I think sometimes academia is a bit frightening. When the work is done, or just begun, in being successful and appointed, a colleague advises 'watch your workload', 'learn to say no'. The colleague, like us all, has other motivations and agendas, and I reel in the advice while 'working my load'.

Walking home I think about this work. The funding bids and publications we have worked on over the past year take place outside the scope of my then 0.7 FTE post. I am certain that supporting me like this - informally, at Christmas - is not recognized as part of The Feminist Professor's workload. When 'future leader' and 'starting grant' and 'early career fellowship' schemes ask me to identify a mentor at the host institution this role, this work, is not costed into the grant. Achievements-plans-visions, I write these headings out again and again over the next fortnight, at the top of blank pages in notebooks, headings on slides, preparing for the interview. Achievements-plans-visions 
these categories ask me to be accomplished, aspiring, future-orientated.

\section{Conclusion}

When we tell the stories of our careers, the promise of progression, of becomingacademic, is at once seductive and unsettling. Entrance, individual mobility, and institutional rewards imply recognition and arrival within academia, as something we are encouraged to celebrate. Such arrivals can be read as successful examples of meritocratic meteoric mobilities, and rational, linear, coherent paths - career ladders followed, climbed, and sustained. 'Early' 'mid' and 'established' career categories offer an institutional framework through which academic mobilities, and academic spaces, can be claimed by feminists working in higher education. We have occupied these categories in our collaborations - the established professor mentoring the early career researcher - and we occupy them again in writing this article.

We began with the sense that inhabiting such categories uncritically can serve to re-inscribe neoliberal academic structures, reproducing the idealized striving individual subject focused on their own career advancement, that feminists may seek to resist. Working auto-ethnographically, we explored how feminist collaborations across career categories are ambivalently bound up with the 'hyper-competitive world of higher education' (Hey 2004: 33). Reading categorical career stages and feminist collaboration through each other showed how the often unrecognised labour of mentorship can both claim and disrupt career categories and their associated competitive individualism. Our feminist collaborations have occupied the temporal logics of career stages and individual mobilities, within which we work to justify our own positions and claims as we stretch to apply ourselves in job applications, annual reviews, funding bids, and calls for papers, just as we have bumped up against their hard edges. 
These logics are also re-inscribed on our bodies in space and time, as early career academics sneak round doors and into rooms, swiping into buildings or being swiped in, as we meet 'outside' the university, our bodies are placed by career categories (in place, out of place). Categorical career stages are embodied flushes of shame at being denied entrance as another funding bid is rejected, as another job application is unsuccessful. Not now. Not yet. In the methodological process of writing our conversation together, we both reflected on a sense of being out of time and the creeping sensation of being read and positioned as 'too late' (for early career funding) and 'too early' (too young to be a Professor). Career categories imply academics that are permanently on time (in the right place at the right time). Writing our autoethnographic conversation together allowed us to collage our individual stories, fracturing the on-time and in-place individualism of successful career narratives, as well as to stretch a simplified collaboration-as-resistance reading of cross-career feminist collaboration.

It is tempting to approach feminist collaboration somewhat uncritically, as a warm bath or sustaining bubble of safety within which we can protect each other and work to resist greedy institutional demands. It is clear however, that despite the pleasurable and critical possibilities of feminist collaborations, such ways of working are neither inherently nor automatically resistant to the hyper-competitive individualism that structures our workplaces, and that we reproduce (in publishing, in generating income). When we take up space within categorical career stages, collaborate across them, take pleasure in our achievements and arrivals, and articulate feminist claims within the language of the academic career, we reinscribe their logics of individual mobilities, and this serves the neoliberal university and the structural inequalities it reproduced. 
Exploring cross-career collaborations underscores the need to attend to differences between feminist academics. Gannon et al. (2015: 191) draw on longstanding critiques of falsely universalized notions of (white, middle-class) 'womanhood' as a unifying identity category to argue that collaborative feminist 'relationalities can bind and exclude, excluding through the binding'. This draws our attention to how collectivity and collaboration can erase differences between feminists, and erase classed and raced exclusions from the feminist academy. This points us to the importance of understanding feminist collaborations as both problem and solution in neoliberal universities.

Thinking through collaboration as problem-and-solution means attending to how ‘women's relational labour is co-opted by educational institutions to perform the work of neoliberal reform' (Gannon et al 2015: 189, 194). Cross-career feminist mentorship in higher education then, can be read in part as individualising the work of supporting early career and casualised employees, which arguably arises from the structures of neoliberal academia and should be a collective responsibility. If a mentoring relationship supports individuals to survive and progress through the insecurity and uncertainty of early career, this work can be understood as individualising, instead of or as well as collectivising; supporting early career academics within the terms of the career course, rather than (or as well as) working to transform structural conditions of insecurity and uncertainty. Here we pause to consider how the feminist project of supporting 'younger' academics can ambivalently do the work of remediating a lack of institutional care and accountability.

Our conversation shows that in practice, feminist stretches across career categories entail a much messier experience of 'career stages', even as we successfully, hesitatingly, and ambivalently occupy those categories (a professor, a chancellor's 
fellow). As fixed categories, career stages work to position academics as either precarious or privileged, but our conversation reveals elements of insecurity and uncertainty side-by-side with the security of arrival and achievement. This observation allows us to stretch the meaning of career categories themselves, and writing this article serves as one contribution to a more pluralised and fragmented imaginary of feminist academic work and careers. 


\section{References}

Acker, S and Armenti, C (2004) 'Sleepless in academia', Gender and Education, 16(1): $3-24$

Acker, S and Wagner, A (2017) 'Feminist scholars working around the neoliberal university', Gender and Education [online advance publication]

Addison M (2012) 'Feeling your way within and across classed spaces: The (re)making and (un)doing of identities of value within Higher Education in the UK', in: Y. Taylor (ed) Educational Diversity: The subject of difference and different subjects Basingstoke: Palgrave Macmillan

Ahmed, S (2012) Embodying diversity: Problems and paradoxes for Black Feminists.

In: Taylor, Y. (Ed.), Educational Diversity: the Subject of Difference and Different Subjects. Palgrave Macmillan, Basingstoke.

Ahmed, S (2017) Living a Feminist Life Duke University Press

AHRC (2017) Research Funding Guide

http://www.ahrc.ac.uk/documents/guides/research-funding-guide/ (accessed 10 August 2017)

Alexander, C and Arday, J (2015) Aiming Higher: Race, Inequality, and Diversity in the Academy https://www.runnymedetrust.org/uploads/Aiming\%20Higher.pdf (accessed 25 June 2017)

Angervall, P (2016) 'The academic career: a study of subjectivity, gender and movement among women university lecturers', Gender and Education

Bagilhole, B. and White, K., 2013. Generation and gender in academia. Palgrave Macmillan.

Bhambra, G K (2015) 'Black thought matters: Patricia Hill Collins and the long tradition of African American sociology ${ }^{`}$ Ethnic and Racial Studies 38 (13): $2315-2321$

Breeze, M (2018) 'Imposter Syndrome as a Public Feeling' in Taylor, Y. and Lahad, K. (2018) Feeling Academic in the Neoliberal University Feminist Flights, Fights and Failures. Basingstoke: Palgrave pp. 191-220

Carey (2014) http://www.jobs.ac.uk/careers-advice/working-in-highereducation/2184/from-early-to-mid-career-key-stepping-stones 
Costa, C (2018) 'Digital Scholars: A Feeling for the Academic Game' in Taylor, Y. and Lahad, K. (2018) Feeling Academic in the Neoliberal University Feminist Flights, Fights and Failures. Basingstoke: Palgrave pp.345-367

Davies, B and Gannon, S (2012) 'Collective Biography and the Entangled Enlivening of Being', International Review of Qualitative Research 5(4):357-376

De Cruz, H (2016) Happily ever after? Advice for mid-career academics https://www.timeshighereducation.com/blog/happily-ever-after-advice-midcareer-academics\#survey-answer (accessed 13 March 2017)

Equality Challenge Unit (2017) Equality in higher education: statistical report 2017 https://www.ecu.ac.uk/publications/equality-in-higher-education-statisticalreport-2017/ (accessed 11 December 2017)

ERC (2017a) Starting Grants https://erc.europa.eu/funding/starting-grants (accessed 10 August 2017)

ERC (2017b) Consolidator Grants https://erc.europa.eu/funding/consolidator-grants (accessed 10 August 2017)

ESRC (2017) Additional support for early career researchers http://www.esrc.ac.uk/news-events-and-publications/news/newsitems/additional-support-for-early-career-researchers/ (accessed 10 August 2017)

Foster, D (2016) Lean out Watkins Pub Ltd

Gabriel, D and Tate, S.A (2017) Inside the Ivory Tower: Narratives of women of colour surviving and thriving in British academia London, UCL IOE Press

Gannon, S Kligyte, G McLean, J Perrier, M Swan, E Vanni, I and van Rijswijk, H (2015) 'Uneven relationalities, collective biography, and sisterly affect in neoliberal universities', Feminist Formations 27(3): 189-216

Gannon, S Powell, S and Power, C (2018) 'On the thresholds of legitimacy: a collaborative exploration of being and becoming academic', in Y Taylor and $\mathrm{K}$ Lahad (eds.) Feeling Academic in the Neoliberal University: Feminist Flights, Fights and Failures pp. 261-281

Gill, R (2010) 'Breaking the silence: The hidden injuries of neo-liberal academia', in Flood, R and Gill, R (Eds.) Secrecy and Silence in the Research Process: Feminist Reflections London: Routledge

Gill R (2014) 'Academics, Cultural Workers and Critical labour Studies', Journal of Cultural Economy 7(1): 12-30 
Gill, R and Donaghue, N (2016) 'Resilience, apps and reluctant individualism:

Technologies of self in the neoliberal academy', Women's Studies International Forum 54:91-99.

The Guardian (2015) In pictures: the women leading the UK's top universities https://www.theguardian.com/women-in-leadership/gallery/2015/mar/17/inpictures-the-women-leading-the-uks-top-universities (accessed 13 March 2017)

Handforth, R and Taylor, C A (2016) 'Doing academic writing differently: A feminist bricolage', Gender and Education 28(5): 627-643

Harding, S. (1997) Comment on Hekman's 'Truth and Method: Feminist Standpoint Theory Revisited'. Signs. vol. 2, no. 2, pp. 375-381.

Hartstock, N (1997) Comment on Hekman's 'Truth and Method: Feminist Standpoint Theory Revisited'. Signs. vol. 2, no. 2, pp. 367-374

Henderson, E. F. (2018) 'Feminist Conference Time: Aiming (Not) to Have Been There' in Taylor, Y. and Lahad, K. (eds) (2018) Feeling Academic in the Neoliberal University: Feminist Flights, Fights and Failures. Basingstoke: Palgrave, pp.33-60

Hey, V 2001 The construction of academic time: Sub-contracting academic labour in research Journal of Educational Policy, 16 (1) (2001), pp. 67-84

Hey, V 2004 Perverse pleasures - Identity work and the paradoxes of greedy institutions Journal of International Women's Studies, 5 (3) (2004), pp. 33-43

Hill Collins, P (1990) Black Feminist Thought: Knowledge, Consciousness, and the Politics of Empowerment. Routledge, London.

Holloway, G (1997) 'Finding a voice: on becoming a working-class feminist academic', in Mahony, $\mathrm{P}$ and Zmroczek, C (eds) Class Matters: Working class women's perspectives on social class Oxon: Taylor and Francis pp.190-199

Leathwood, C (2013) Re/presenting intellectual subjectivity: gender and visual imagery in the field of higher education, Gender and Education, 25(2):133-154

Leathwood, C and Read, B (2009) Gender and the Changing Face of Higher Education: A Feminized Future?: A Feminized Future? Open University Press

Mirza, H. S (1997) Black British Feminism: A Reader London, Routledge

Mirza, H. S (2017) “"One in a million”: a journey of a post-colonial woman of colour in the White academy', in Gabriel, D and Tate, S.A (eds) Inside the Ivory Tower: Narratives of women of colour surviving and thriving in British academia London, UCL IOE Press pp.39-54 
Morely, L (1997) 'A class of one's own: women, social class, and the academy' in P Mahony and C Zmroczek (eds.) 'Class Matters': Working Class Women’s Perspective on Social Class, London: Taylor and Francis pp. 109-122.

Morely, L (2013) 'The rules of the game: Women and the leaderist turn in higher education', Gender and Education 25(1): 116-131

McRobbie, A (2009) The aftermath of feminism: gender, culture and social change London: Sage

Pearce, R (2017) 'Certifying Equality? Critical reflections on Athena SWAN and equality accreditation' Coventry: Centre for the Study of Women and Gender.

Pereira, M (2012) “Feminist theory is proper knowledge, but ...': The status of feminist scholarship in the academy', Feminist Theory 13(3): 283-303

Pereira, M (2016) 'Struggling within and beyond the Performative University: Articulating activism and work in an "academia without walls", Women's Studies International Forum, 54: 100-110

Pereira, M (2017), Power, Knowledge and Feminist Scholarship: an Ethnography of Academia, London: Routledge.

Quinn, J Allen, K Hollingworth, S Maylor, U Osgood, J and Rose, A (2014) 'Dialogue or duel? A critical reflection on the gendered politics of engaging and impacting', in Y Taylor (ed) The Entrepreneurial University: Engaging Publics, Intersecting Impacts Basingstoke, Palgrave Macmillan

Reay, D (1997) 'The double-bind of the "working class" feminist academic: the success of failure or the failure of success?' in Mahony, P and Zmroczek, C (eds) Class Matters: Working class women's perspectives on social class London: Taylor and Francis pp. 18-29

Redmond, P Gutke, H Galligan, L Howard, A and Newman, T (2017) 'Becoming a female leader in higher education: investigations from a regional university', Gender and Education 29(3):332-351

Skeggs, B (1995) 'Women's studies in Britain in the 1990s: Entitlement cultures and institutional constraints', Women's Studies International Forum 18(4): 475-485

Smith, D.E. (1997) Comment on Hekman's 'Truth and Method: Feminist Standpoint Theory Revisited'. Signs. vol. 2, no. 2 pp. 392-398

Southerton, D (2003) 'Squeezing Time' Allocating Practices, Coordinating Networks and Scheduling Society, Time and Society 12(1): 5-25 
Spanó, E (2017) ‘Femina Academia: women ‘confessing' leadership in Higher Education, Gender and Education [early online access]

Stanley, L (1993) 'On auto/biography in Sociology', Sociology 27(1): 41-52

Tauqir, T., Petzen, J., Haritaworn, J., Ekine, S., Brackle, S., Lamble, S., Jivraj, S., Douglas, S., (2011) Queer anti-racist activism and strategies of critique: A rountable discussion. Feminist Legal Studies 19, 169- 191.

Taylor, Y (2012) 'Facts, Fictions, Identity Constrictions: Sexuality, Gender and Class in Higher Education' in Y Taylor (ed) Educational diversity: the subject of difference and different subjects Basingstoke: Palgrave Macmillan

Taylor, Y (2013) 'Queer encounters of sexuality and class: Navigating emotional landscapes of academia', Emotion, Space and Society 8: 51-58

Taylor, Y (2014) (ed.) The Entrepreneurial University: Engaging Publics, Intersecting Impacts. Basingstoke: Palgrave Macmillan

Taylor, Y. and Lahad, K. (eds.) (2018) Feeling Academic in the Neoliberal University Feminist Flights, Fights and Failures. Basingstoke: Palgrave

Thwaites, R and Pressland, A. (2016) Being an early career feminist academic in a changing academy: Global perspectives, experiences and challenges Palgrave.

UNESCO (2014) http://www.uis.unesco.org/Education/Pages/women-highereducation.aspx\#sthash.USwUme3I.dpuf

Wakeling, P (2010) 'Is there such as thing as a working-class academic', in Y Taylor (ed.) Classed Intersections: Spaces, Selves, Knowledges Birmingham, Ashgate Walker, M (1997) 'Women in the Academy: Ambiguity and complexity in a South African university', Gender and Education, 9(3):365-381 